Др Јован М. Делић

\title{
УЗ СОНЕТЕ МИЛУТИНА БОЈИЋА
}

Четрдесет седам сонета - а толико их је испјевао Милутин Бојић за свога кратког вијека - чине респектабилан сонетни опус за једног двадесетпетогодишњака. Ти сонети су настали „у класичном раздобљу сонета у српској поезији“. Тридесет два сонета чине Бојићев „канцонијер“ са темом љубави у своме средишту, а то је љубав под маскама, или са маском, али и љубав послије пада маски и љубавног идола. Бојић пјева о противурјечности и сложености љубавног осјећања, о драматичном односу љубави и мржње, али има и сонет као програмску пјесму, као и пјесму са наглашеним родољубивим осјећањем и темом националног страдања. Бојић се и у сонетима показује као вјешт версификатор који посебну пажњу поклања „сонетном коленцу“, односно преласку из катрена у терцете.

Кључне ријечи: Сонет, „канцонијер“, циклус, тематика, „коленце“, драга, маска, женско тијело - васељена, пад идола.

Бојић за живота није важио за сонетисту, не барем за значајнијег који је дао печат развоју сонета код Срба. Тек 1922. године - пет година послије пјесникове смрти - појавила се његова збирка сонета са укупно тридесет двије пјесме. То, међутим, није било све: у Сабраним gелима, у петом дијелу прве књиге (Поезија), у одјељку Соне $\bar{u} u$, штампано их је још једанаест што ће рећи - укупно четрдесет три пјесме. Али понеки сонет је штампан изван „збирке“. Сонетну форму имају и пјесме: Онима щйио йлачу и Мећава - једна од најбољих Бојићевих пјесама - па Химна и Језера, што би значило да је до сада познато четрдесет седам Бојићевих сонета. А то нипошто није мало; то је респектабилан сонетни опус, поготово за једног двадесетпетогодишњака.

Гаврило Ковијанић подсјећа у својој докторској дисертацији о Бојићу да је сонет „у периоду изгнанства“ био његован облик и наводи Царске сонетеие Јована Дучића, Косовске сонейе Божидара Пурића, Албанске сонейе Јанка Лаврина и Сонетие стираgања Светислава Стефановића - пет сасвим репрезентативних збирки, укључујући и Бојићеву. 
У раду о Бојићевим сонетима, рађеном за зборник о Бојићу и Институту за књижевност и уметност у Београду, др Сања Париповић Крчмар подвлачи да Бојићеви сонети падају „у времену изразите сонетне проширености на почетку 20. века“, које се узима као „класично раздобље сонета у српској поезији“, када су сонете писали Јован Дучић, Милан Ракић, Владислав Петковић Dis, Сима Пандуровић, Алекса Шантић, Милутин Бојић, Мирко Королија, Милан Ћурчин, Светислав Стефановић, Димитрије Митриновић, Велимир Рајић... и упућује на Анйолоїију срйской сонейа Драгутина Вујановића (1995).

Послије аналитичког увида у структуру Бојићевог сонета, Париповић Крчмар рехабилитује и реактуализује закључак Владете Вуковића као „најсуптилније решење којим се не занемарује траг, односно одзвуци лектире, а уједно се песнику придаје димензија самосвојности“. А Вуковићев закључак је да „и поред свих утицаја и местимичних позајмица, Бојић несумњиво представља мост од песничких остварења Ракића и Дучића ка другим модерним токовима у српској поезији“. Према нашим увидима, али и према увидима колегиница и колега који су учествовали на научном скупу о Бојићу, сличан суд би се могао проширити на цјелокупно Бојићево пјесништво.

Како читати и тумачити Бојићеве сонете, њих четрдесет седам?

Вјероватно онако како су и објављивани - у контексту појединачних збирки, или појединчано, а тридесетдва сонета објављена у збирци Сонеиии - као циклус, односно као мали канцонијер. Између четрдесет три засебно штампана сонета у Сабраним делима издваја се тридесет пети (XXXV) својом тематском усмјереношћу и програмском природом, а никако не припада осталима као цјелини. Он је, у тематском погледу, више варијација уводне пјесме за књигу Песме бола и йоноса и у том погледу је уникатан. То је једини патетичан „отаџбински“, патриотски у збирци од четрдесет три сонета у Сабраним gелима, а и у свих четрдесет седам сонета, колико их је Бојић саставио. Само му се по тематици дјелимично приближава неупоредиво бољи сонет Мећава; једна од најбољих Бојићевих пјесама уопште.

Оба катрена и први терцет XXXV сонета почињу питањем: Гуслари, $\bar{\imath} g e c \bar{u} e ?$ - које постаје рефрен и испуњава први чланак јампског једанаестерца (5+6) у којем је пјесма испјевана. Пјеснички субјекат зазива гусларе

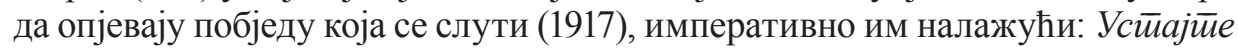
свейле gа славиие дане!

Зашто рефрен-питање изостаје у посљедњем терцету?

Због сонетног обрта који не почиње с првим терцетом, већ тек са његовим трећим стихом, па се онда наставља у завршном терцету, да би се слављеничко гусларско епско пјевање замијенило људским ћутањем и плачем вјекова над страдањем, погибијама и подвизима. Пјесничком гласу одговара глас из гробља, па је сонет двогласан. Том другом гласу припадају завршна четири стиха. То је глас вјековног искуства, глас мртвих: 
Већи сте од нас! Из гробља се зачу.

Из сваког срца већа песма тече

Но што је могло гудало да рече, Јер људи ћуте кад векови плачу.

Ћутање људи и плач вјекова су рјечитији од гусларског, пјевачког, епског слављења подвига и побједа. Иза свих побједа остају гомиле мртвих и народно страдање.

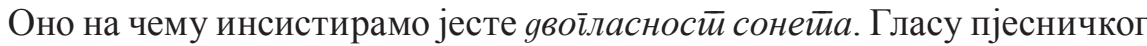
субјекта одговара глас гробља, глас вјекова и мртвих, и то ваља истаћи и запамтити.

Прво ћемо се осврнути на Бојићеву збирку од тридесет два сонета као на сонетни циклус - пјесников канцонијер - а потом ћемо видјети у каквом је односу преосталих десет сонета према том канцонијеру, пошто смо тридесет пети већ прокоментарисали. Тако ћемо поштовати пјесникову аутономију - његову ауторску намјеру и његову једину сонетну збирку, али и цјелокупност његовог сонетног опуса -а опет стећи увид у цјелину сонетног опуса.

Бојићеви сонети су љубавни, како и приличи традицији италијанског сонета, на коју се овај сонетиста, све су прилике, наслања. Сваки од њих тридесет два адресован је на драгу, здраву и живу, често идеализовану, али је она - идеализацији упркос - далеко од идеалне драге. Тако канцонијер постаје својеврсна љубавна драма под маскама о срушеном љубавном идеалу. Пјевање о драгој преображава се у ијеваъе о маскама, чиме се прави снажан отклон од италијанске традиције и хвата прикључак с идејама авангарде. То на први поглед изгледа необично, али тако показује анализа текста.

Одмах треба рећи да се Бојићева сонетна поезија изразито разликује од остале његове љубавне поезије: тон је мекши, приснији, интимнији, страсти су стишане и стилизоване, а поготово тјелесност. Када тематизује тијело и тјелесно, то је, по правилу, у функцији дочаравања физичке љепоте. Да ли је ту пресудна конвенција, односно снажна сонетна, превасходно италијанска традиција? Вјероватно. Али пјесник је прије свега свој, ако је прави.

А Бојић је, изгледа, и свој и прави и у сонетима. Његов канцонијер је препознатљив. У четвртом сонету љепота вољене жене поништава васељену и добија васељенске размјере. Женско тијело је пројекција космичких вриједности. То је највећи израз тјелесности у Бојићевим сонетима. У том знаку су оба катрена четвртог сонета:

За мене ноћас васељене није,

Очи су твоје сунца, звезда, дуге, Усне скуп сласти, осмеха и туге, Косе дах мора и шуштање шума. 
Срце звук песме што пожудно бије,

Реч час заповест, час понизност слуге,

Циљ си ком воде сви пути, све пруге,

Пред ким се ништи гордост људског ума.

И први терцет припада том времену стварања нових светеиова који ће бити и своји - свјетови љубавника; припада времену љубавног заноса у којем се ствара идеална драга пројектовањем васељене у њену идеалну маску:

Стварајмо собом видике и боје,

Светове нове, но светове своје!

Ноћас само за тебе желим знати.

Ово ноћас, упркос граматичком презенту, припада, ипак, прошлости. То је некадашње ноћас, упркос основном значењу ове лексеме. И то постаје законитост у Бојића: вријеме љубавних идеала је прошло; маске су пале. Прошлост припада љубавном сну, без обзира на жеље лирског субјекта да својој драгој дадне иелоі себе. То се није десило и неће се, нити се може десити. Прави преокрет долази са завршним терцетом:

Те ноћи то сам само рећи знао.

Па ипак само ја сам сан ти дао,

А мислио сам целог себе дати.

Уводни сонет, који по правилу има метапоетску функцију, тематизује маске и уклапа се у идеје прве четвртине двадесетога стољећа у српској књижевности. Испјеван је у трохејском симетричном дванаестерцу са системом римовања abba, abba, cde, cde. Риме су правилне, женске, а међу њима препознајемо Ракићеве римоване лексеме (ираске, ласке).

У правом катрену се пјева о „старој причи“ gа носимо маске и да смо глумци у лажним улогама у животној арени лажи. Спазивши бинске gаске нове једне позорнице, лирски субјекат, у другом катрену, сматра да је открио простор и свијет истине у којем се презиру свјетска ласкања и лажи.

Преокрет доноси већ први стих првога терцета - йag иgола и губитак лажног сјаја; претварање бљеска у труо костур, па се лирски субјекат, умјесто сред врта, налази пред гробом, одакле на њега с презрењем падају змије. Одједном се отвара доњи, подземни свијет проклетства, опасности и мрака. Страховити тресак пада доводи лирског субјекта до горког сазнања да је и пред самим собом био глумац, односно да му је живот неаутентичан и лажан. Тек се падом открива истина:

Данас паде идол и сав сјај се отре, У костур се труо претвори сав блесак.

Место усред врта нађох се пред гробом. 
Одакле с презрењем на ме змије мотре.

O, разумем пада страховити тресак:

Ја сам био глумац и пред самим собом.

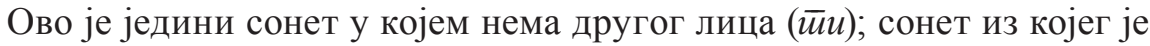
одсутна драга жена. Она се јавља већ од другог сонета.

Од другог, па закључно са тринаестим сонетом Бојић мијења стих и ритам - наредних дванаест сонета испјевано је у јампском једанаестерцу $(5+6)$. Још једна промјена је изразито уочљива, па се, можда, може говорити о Бојићевој иновацији у сонету. Почевши од другог, па закључно са XXIII сонетом Бојић у катрене уводи $\bar{u} p e \hbar y ~ p u м y-c$ риму - па систем римовања у катренима је по правилу $a b b c, a b b c$.

Бојићеви сонети настају из горчине сазнања - да драга о којој пјева

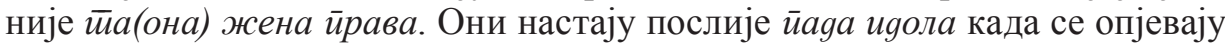

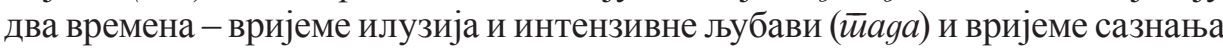
о паду и правој природи некад идеализоване жене ( gанас), што је најизразитије у трећем сонету. Лирски субјекат је некад у драгој видио све:

Јер видео сам све у теби тада:

Сунца и сестре, матере и сене,

Звуке и боје, реч и дрхтај пене.

У мозак мој је дах твој био уткан.

Љубавници су се међусобно прожели: њен дах је био уткан у његов мозак, а она постоји као идеализација, као субјективна идеална пројекција лирског субјекта; као маска идеалне драге.

Бојићеви сонети живе од тога напона између слике идеалне, створене, измишљене драге која припада времену прошлом ( $\bar{u} a g a)$, и срушеног идола,

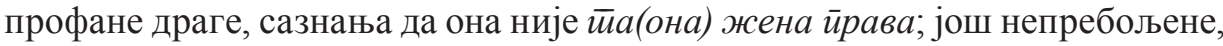
али бивше драге, која припада времену саga и gанас.

Зато лирски субјекат одбија данас часе јаgа, иако су страсти умирене, јер је некадашња драга још лијепа, йуна майле снене, и он би желио да је сачува и запамти као икону оg зла щйио сйасава. Зато би желио да је врати васељени, од које ју је створио сањарењем - о чему, видјели смо, пјева IV сонет - али му се, као поента, враћа питање о маски и варци, о неаутентичности вољене жене:

И зато данас нећу часе јада

И болни уздах цвета који вене,

Јер још си лепа, пуна магле снене,

Мада у мени крик страсти је сћуткан.

Стог бежи таква, маглена, прозирна, Да запамтим те увек такву исту, Као икону од зла што спасава. 
Распи се у прах ко звезда свемирна

И да те сањам блештаву и чисту

Што ти не беше она жена права.

Расйи се у йрах ко звезяа свемирна, препоручује лирски субјекат астрални крај драгани, како не би доживјела профани, земаљски пад. Створена сновима од космичких елемената - Снови су моји иееби вреgности gали (VI) - она се, такође сновима, враћа у астрални прах, као звијезда падалица; као што се расипа бог Пан који И смрћу иесму о лейотии gаgне: / Камени Пан се у poj звезgа pacy (XVIII). Лирски субјекат узалудно покушава да спасе икону og зла щйио сйасава, јер - умјесто спасења од зла - његовој души предстоји проклето лутање и вјечна самоћа, како казује поента II сонета, у чијем се правом стиху поставља питање: $O$ защйо ниси тии ий жена йрава, а у терцетима се сагледава нов пут лирског субјекта:

И место мира нов пут ми предстоји, Да лажем себе у ком новом храму Душа се моја сама себе боји,

Јер види себе пусту, вечно саму, Као Ахасфер да бесциљно блуди, Клета од оних за којим се жуди.

Природно је онда што у Бојићевим сонетима нема за Бојића карактеристичне поезије страсти: страст је сћуйкана падом маски, рушењем идола, губитком идеалне драге и њеним преображајем у „неправу“ жену. Умјесто експлозији страсти присуствујемо непрестаној, тихој љубавној драми и пригушеној патњи, што нужно слиједи из унутарње „логике“ Бојићевог канцонијера.

Остао је, међутим, усклик жуgи која вечно ӥраје и израз те жуди са еротским патосом подсјећа у XXXII сонету на Бојићеве пјесме страсти крај пољупца је знак смрти:

O, нек ти рекне тај пољубац што се

Свршава новим пољупцима, да је

То усклик жуди која вечно траје,

Песма усана што се крвљу росе.

И преко вода чежњу страсти носе,

Купећи сунца и цвеће и краје,

Жуд лудих ноћи када разум стаје

Да спусте теби на усне и косе

И да усаде у зенице твоје

Мирисе, звуке и звезде и боје;

И ко победник што гине на мети 
Уз шумни пљесак крај у њему стечем

И да ти њиме песму сунца речем

Кад раставити усне значи: мрети.

У тражењу, слутњи и открићу љубави љубавници долазе до сазнања о почетку своје везе која је дубља и старија од првога сусрета, како откривају терцети и поента XIV сонета:

Обоје за истом жудили смо сликом, Вођени нејасним лутали смо дуго, Ко да назирасмо мраком једно друго,

И рекосмо реч, што не рекосмо ником На сусрету првом, мада нисмо хтели, Ми смо се волели, пре но смо се срели.

Љубав, дакле, зна бити старија и дубља од првог сусрета љубавника и може се јавити као парадоксално старо откриће. Сличан доживљај љубави наћи ћемо знатно касније - у Матије Бећковића.

Једно $\bar{u} u$ у Бојићевим сонетима није драга, већ сунчани зрак, и тај сонет о сунчаном зраку (VIII) једна је од најљепших Бојићевих љубавних пјесама уопште.

Зрак долази од ње - драгане - лирском субјекту, невин и несвјестан шта му значи и доноси. Он је - зрак - миловао њене косе, дао сјај њеном оку, понио у свом дрхтају њене осмјехе, дах и мирис, па лирски субјекат жели да се око њега тај зрак свије као замјена за драгану и да у његовој души яубок яуби корен:

Ти идеш од ње, ти, сунчани зраче,

Ти си јој косе миловао, мада

Сам ниси знао на шта сјај твој пада.

И њеном оку ти си дао сјаја.

У твој се дрхтај ненадно увлаче

Осмеси њени фини, ко тон јада.

Тих осмеха је моја душа рада.

Зраче, жељен сам твога загрљаја.

Јер дршћеш препун пурпурнога праха,

Мириса њеног осмеха и даха,

Сав око мене хоћу да се свијеш.

Не распи живот свој случајем створен,

У душу моју дубок дуби корен;

Стани, јер не знаш шта у себи кријеш.

Љубав је посредована сунчаним зраком, као што ће други пут лирски субјекат послати ноћу поздрав драгој йо олују (XXII): 
По олују ти ноћас поздрав шаљем.

(...)

И нек твој лепи лик му тутањ смири,

Да стане, да те помилује меко

И да отхуји далеко, далеко.

И док се твоје око тихо шири

И око тебе низ мириса плете,

Да чујеш моју душу пуну сете.

Космичко и женско су код Бојића у честој вези: сунчев зрак је кадар да принесе пурпурни прах жениног мириса, осмијеха и даха, сјај њенога ока и њежност косе, као што је лейи лик жене способан да смири тутањ олује и кроз тај тутањ осјети gyщuy йyну сейе свога драгана.

Бојић прониче у противурјечности љубавног осјећања препознајући елементе садизма у драганином односу (XXVII):

Ти си ми срце узела што плама

Да пакосно се сладиш новом раном.

Још је драматичнији однос љубави и мржње у XXXIX сонету у којем је дочаран најсложенији и најпротивурјечнији однос емоција несрећно заљубљеног човјека. Драги жели своју драгану и кад га њена ријеч заболи; воли је и када је мрзи; жели је и кад га бол због ње обузима. По неразумним поступцима заљубљени човјек је близак лудаку: јада се због бола оној која му је тај бол нанијела. Такви стихови су као мала антрополошка открића доста ријетки у нашој љубавној поезији, па би овај XXXIX Бојићев сонет ваљало запамтити:

Зашто кад ме твоја реч горко заболи

И када кроз тебе све у мени плаче,

Привлаче ме теби све више и јаче

Неки непојамни таласи и тмоли?

И када те мрзим, тад мој бол те воли

И док моју душу твоји греси тлаче,

Ко очајник с чијег чела сјај се смаче,

Желим те тад, кад ме бол због тебе сколи.

И ником не могу бол у срце скривен,

Бол, у тешки терет ко од туге сливен,

Рећи тако топло, сав патњама сморен.

И ја као лудак у бунило падам

И хтео бих да се само теби јадам

За тај бол који је баш од тебе створен. 
По тој противурјечности и сложености опјеване љубави, Бојићу припада лијепо мјесто међу нашим сонетистима; љепше него што га сада има. Те пјесме су боље од оних у којима се љубавна драма расплиће, а драга са императивом шаље да тоне у калу (XXXIV):

\section{Одлази од мене и тони у калу.}

Или када јој се прориче да ће бити йрезрена оg свију, уз рефрен на крају катрена: Ти си ииако хйела (XXXVII).

Бојић нам је мање убједљив у својим „грешним сонетима“ (Сеgам смрйних іррехова и Грещни сонети $)$. Ту је мање аутентичан, а недовољно спреман да се понесе с темама које су свјетски пјесници прославили, па у том контексту ови сонети дјелују блиједо и књишки.

Бојићу припадају сви комплименти што је спојио традицију љубавног сонета с авангардном идејом маске као и што је у сонету Мећава такође бриљантно спојио такорећи непосредно, пријесно, сурово животно избјегличко искуство човјека у повлачењу кроз зимски пејзаж са потпуно инверзном сликом космоса и односа горе-доље, поредивом са Растком Петровићем. Сонет Језера такође је једна од неправедно заборављених и скрајнутих Бојићевих пјесама, а зацијело је ријеч о изузетном споју слике женских очију и дијела природе - васељене, рекао би пјесник - што је у сонетима једна од његових специфичности. То је такође пјесма коју смо високо оцијенили и о којој, као и о Мећави, пишемо на другом мјесту.

Бојићеви сонети заслужују пуну читалачку и критичку пажњу. У њима пјесник достиже можда најтананије своје лирске вибрације, па и антрополошка открића када је о човјековим сложеним и противурјечним емоцијама ријеч. Са сонетима је Милутин Бојић много комплетнији лиричар српске модерне који и сонетима наговјештава долазак аванграде, показујући у појединим идејама и сликама - маске и космичка инверзија - блискост Милошу Црњанском и Растку Петровићу. Овом контексту припада такође у сонету испјевана Бојићева Химна, пјесма која се може сагледавати на линији Дис - Бојић - Црњански. О том је већ било раније ријечи. Овдје је у средишту пажње Бојићев сонетни љубавни циклус, мали канцонијер.

Ствари не стоје сасвим онако како их је видио Винавер.

Jovan M. Delić

ACCOMPANYING THE SONNETS OF MILUTIN BOJIĆ

Sum mary

Bojić's two books of poetry are usually mentioned: Pesme (Poems) and Utopljene $d u \check{s}$ e (Drowned Souls), and much less frequently - the posthumously published Soneti 
(Sonnets) with a total of thirty-two poems. Bojic wrote a total of forty-seven sonnets; among them some of his best poems ( „Mećava“/Blizzard/, „Jezera“/Lakes/).

We see thirty-two poems in the collection Soneti as Bojić's ,canconier“, i.e. a collection of sonnets addressed to a concrete, living darling, first idealized, and then ,without a mask" - as the embodiment of broken love ideals. Thus, the „canzonier“" becomes a lyrical love drama under the guise of a broken love ideal. Hence the distinctly emphasized presence of the second person singular in Bojićs sonnets. Writing about the darling is transformed into writing about masks, which establishes a departure from the Italian tradition of the love sonnet and captures the connection with the ideas of the avant-garde. Bojic's sonnets differ from his other love poetry: the tone is softer, closer, and more intimate; passions are silenced and stylized; corporeality is in the function of evoking physical beauty.

Bojić evokes a complex relationship between the love and hate of an unhappily in love man; an internal emotional contradiction, so such verses are small anthropological revelations.

Not all of Bojić's sonnets are collected in this book: he wrote - according to our insight - a total of forty-seven, thematically diverse and mostly successful ones. He combined the tradition of a love sonnet with the avant-garde idea of a mask, and in the sonnet „Mećava“ (Blizzard) - a cruel refugee experience of a man retreating through a winter landscape with an inverse image of the cosmos, comparable to Rastko Petrović. The sonnet „Himna“ (Hymn) also belongs to the pre-avant-garde context and the shift of the genre that is visible on the line Dis - Bojić - Crnjanski.

Milutin Bojić is an important sonnetist, ,in the classical period of sonnets in Serbian poetry“; a poet of a distinctive and recognizable voice. He made a serious contribution to the history of the Serbian sonnet.

Универзитет у Београду

Филолошки факултет

Катедра за српску књижевност са јужнословенским књижевностима 